\title{
Stereoselective Transport of Human His27- and Arg27-Reduced Folate Carrier
}

\author{
Tomoya Narawa,* Hideaki Yanagisawa, and Tomoo Itoh \\ School of Pharmacy, Kitasato University; 5-9-1 Shirokane, Minato-ku, Tokyo 108-8641, Japan. \\ Received October 12, 2013; accepted November 28, 2013
}

\begin{abstract}
The stereoselective transport of methotrexate (L-amethopterin, L-MTX) and its antipode (D-amethopterin, D-MTX) by human reduced folate carrier (hRFC) has been examined in HEK293 cells expressing H27hRFC and R27-hRFC. The uptake of both L-MTX and D-MTX increased as the extracellular pH increased from 6.0 to 7.4. The initial uptake rate of L-MTX into the H27- and R27-hRFCs of the HEK293 cells followed Michaelis-Menten kinetics with $K_{\mathrm{m}}$ values of approximately 0.24 and $0.47 \mu \mathrm{M}$, respectively. Dixon plots revealed that the $\left[{ }^{3} \mathrm{H}\right]-\mathrm{L}-\mathrm{MTX}$ uptake mediated by the H27- and R27-hRFCs was inhibited competitively by unlabeled L-MTX with $K_{\mathrm{i}}$ values of approximately 0.1 and $0.5 \mu \mathrm{M}$, respectively. D-MTX also competitively inhibited the H27- and R27-hRFC mediated uptake of $\left[{ }^{3} \mathrm{H}\right]-\mathrm{L}-\mathrm{MTX}$ with $K_{\mathrm{i}}$ values of approximately 3.4 and $3.2 \mu \mathrm{M}$, respectively. The RFC-mediated uptake clearance of L-MTX was approximately 15-fold greater than that of D-MTX in the H27-hRFC-HEK293 cells, and was more than 30-fold greater than that of D-MTX in the R27-hRFC-HEK293 cells. The results of the current study have revealed that the enantiomers of MTX enantiomers can be transported in a stereoselective manner by the H27- and R27-hRFCs because of significant differences in the affinities of the enantiomers to the hRFC.
\end{abstract}

Key words methotrexate; amethopterin; reduced folate carrier; single nucleotide polymorphism; stereoselective transport

Folates are essential nutrients for cell growth and are transported across cells membranes in a variety of different mammalian cells by the reduced folate carrier (RFC, SLC19A1) or the proton-coupled folate transporter (PCFT, SLC46A1). ${ }^{1-4)}$ The cDNA of the RFC has been cloned in mice, hamsters, and humans, and its transport characteristics have been revealed. $^{5-11)}$ RFC is expressed in the plasma membrane of a variety of different cells and transports reduced folates, with the maximal level of transport being observed at neutral $\mathrm{pH}^{2,4,12)}$ In contrast, PCFT is expressed in the epithelial cells of a range of different tissues, including the liver, kidney, and placenta. Among these tissues, the expression of PCFT appears to be at its greatest in the small intestine, ${ }^{3,13)}$ where it is expressed in the apical membrane of epithelial cells and is involved in the absorption of reduced and oxidized folates using ${\text { a } \mathrm{H}^{+} \text {gradient as its driving force. }}^{12)}$

Methotrexate (L-amethopterin, L-MTX) is used clinically as an antineoplastic and antirheumatic drug. Orally administered L-MTX is actively absorbed by PCFT in the small intestine, with the process being driven by a $\mathrm{H}^{+}$gradient, because its molecular structure is similar to that of folic acid (FA). D-Amethopterin (D-MTX) is the optical isomer of L-MTX, and the absorption of D-MTX from the human small intestine is significantly lower than that of L-MTX. It has been reported that oral absorption of L-MTX is approximately 40-fold greater than that of D-MTX. ${ }^{14)}$ In our previous studies using hPCFTexpressing HEK293 cells, the transport of the MTX enantiomers by PCFT was revealed to be highly stereoselective with the uptake clearance of L-MTX being approximately 40 -fold greater than that of D-MTX. ${ }^{15}$ )

RFC is expressed in the body to a much greater extent than PCFT, and is responsible for the uptake of reduced folates in a number of different cell types. ${ }^{16)}$ It is well known that there are differences in the transport characteristics of PCFT and

The authors declare no conflict of interest.
RFC. For example, PCFT-mediated transport occurs much more readily at acidic $\mathrm{pH}$, whereas $\mathrm{RFC}$-mediated transport is optimal at neutral $\mathrm{pH}$. PCFT transports both oxidized and reduced folates, whereas RFC only transports reduced folates. As mentioned above, the transport of the different enantiomers of amethopterin by PCFT is highly stereoselective. Interestingly, however, the stereoselectivity of RFC-mediated transport has not yet been examined. Although the homology of the amino acid sequences between RFC and PCFT is only about $10 \%$, both of these transporters have common substrates (i.e., reduced folates). With this in mind, we examined the stereoselective transport of RFC using the enantiomers of amethopterin, which possess a similar structure to that of the reduced folates.

A single nucleotide polymorphism (SNP) of hRFC has been reported, involving the substitution of a guanine with an adenine (G80A), with the change resulting in the replacement of a histidine residue (H27) with an arginine (R27). ${ }^{17)}$ The frequency of allele A has been reported to be 0.484 in Ashkenazi-Jewish, 0.564 in African-Americans, 0.472 in Hispanics, 0.473 in French, and 0.56 in Japanese. ${ }^{17-19)}$ Given that the allele frequencies are similar in G80 and A80, we embarked upon a study to examine transport properties of the H27- and R27-hRFCs.

In the current study, human embryonic kidney (HEK) 293 cells stably expressing His27-hRFC (H27-hRFC) and Arg27hRFC (R27-hRFC) were established, and the stereoselective transport of the enantiomers of amethopterin by the H27hRFC- and A27-hRFC-HEK293 cells was examined.

\section{MATERIALS AND METHODS}

Materials L-MTX was purchased from Nacalai Tesque (Kyoto, Japan). D-MTX was purchased from Kanto Kagaku Co. (Tokyo, Japan). 2-[4-(2-Hydroxyethyl)-1-piperazinyl]ethanesulfonic acid (HEPES), and 2-morpholinoethanesulfonic 
acid (MES) monohydrate were purchased from Wako Pure Chemical Industries, Ltd. (Osaka, Japan). [ $\left.{ }^{3} \mathrm{H}\right]-\mathrm{L}-\mathrm{MTX}$ (specific activity, $31.8 \mathrm{Ci} / \mathrm{mmol}$ ) was purchased from Moravek Biochemicals Inc. (Brea, CA, U.S.A.) and used without further purification. All of the other chemicals used in the study were purchased as the highest possible purity grades available.

Construction of Stably Transfected HEK293 Cells Expressing Human RFC Blood sample was collected from healthy male volunteers between 21 and 31 years of age. The study was approved by the Ethical Review Board of School of Pharmacy and Kitasato Institute Hospital, Kitasato University, and the informed consent was obtained from all volunteers. Total RNA from whole blood was isolated using a QIAamp ${ }^{\circledR}$ RNA Blood Mini Kit (Qiagen GmbH, Hilden, Germany). One microgram of the total RNA was heat denatured with $1 \mu \mathrm{L}$ of random primer at $70^{\circ} \mathrm{C}$ for $5 \mathrm{~min}$ before being placed on ice for $1 \mathrm{~min}$ and then mixed with $5 \mu \mathrm{L}$ of Moloney murine leukemia virus (M-MLV) reverse transcriptase $5 \times$ Reaction Buffer, $1.5 \mu \mathrm{L}$ of a $10 \mathrm{~mm}$ deoxyribonucleotide triphosphate (dNTP) mixture, and $0.2 \mu \mathrm{L}$ of M-MLV reverse transcriptase (Promega, Madison, WI, U.S.A.). The mixture was initially incubated at $37^{\circ} \mathrm{C}$ for $60 \mathrm{~min}$, and then incubated at $70^{\circ} \mathrm{C}$ for $15 \mathrm{~min}$. The following oligonucleotide primers were used. Forward primer: hRFC/BamHI 5'-CGGGATCCCTG AGC AGGATGGTGCCC TC-3', reverse primer: $\mathrm{hRFC} / X b a \mathrm{I}$ 5'-GCTCTAGACGCCCGAGA GTCACT GGT TC-3'. The reaction mixture $(50 \mu \mathrm{L})$ contained $1 \mu \mathrm{L}$ of the RT product as the template DNA, $10 \mathrm{pmol}$ of the forward and reverse primers, $10 \mathrm{nmol}$ of the dNTP mixture, $10 \times$ High Fidelity polymerase chain reaction (PCR) buffer, and 1 unit of Platinum Taq DNA Polymerase High Fidelity. Following $2 \mathrm{~min}$ of denaturation at $94^{\circ} \mathrm{C}$, the targeted nucleotides were amplified over 35 cycles (hRFC), with denaturation at $94^{\circ} \mathrm{C}$ for $30 \mathrm{~s}$, annealing at $55^{\circ} \mathrm{C}$ for $30 \mathrm{~s}$, extension at $72^{\circ} \mathrm{C}$ for $2 \mathrm{~min}$, and final extension at $72^{\circ} \mathrm{C}$ for $10 \mathrm{~min}$. The amplified cDNA product was subcloned into a pGEM-T Easy vector (Promega) and transferred into a mammalian expression vector, pcDNA3.1(+) (Invitrogen Co., Grand Island, NY, U.S.A.). The cloned hRFC contained a single mutation (G80A). The alteration at position 80 resulted in an amino acid substitution (R27H). The pGEM-T Easy vector carrying the A80 (H27) RFC was employed as a template for site-directed mutagenesis to create the G80 (R27) construct using the following primers. Forward primer: hRFC (A80G) 5'-CCG GTC CTG GCG GCG CCT CGT GTG CTA CC3', reverse primer: hRFC (A80G) 5'-GGT AGC ACACGA GGCGCCGCCAGGACC-3'. Sequence of each clone was confirmed with an automated DNA sequencer (ABI PRISM 3100: Applied Biosystems, Carlsbad, CA, U.S.A.). There were no mutations except the one for the target position.

The hRFC-expressing HEK293 cells and the control cells (Mock) were constructed by transfecting the expression and control pcDNA3.1 vectors, respectively, into cells using FuGENE 6 (Roche Diagnostics, Indianapolis, IN, U.S.A.), according to the manufacturer's instructions. The transformants were selected using $600 \mu \mathrm{g} / \mathrm{mL}$ of antibiotic G418 sulfate (Nacalai Tesque) over 3 weeks. The uptake study was conducted with several clones and the clone with the highest uptake activity was selected for use in the following experiments.

Cell Culture HEK293 cells were obtained from the Cell Resource Center for Biomedical Research at Tohoku University (Sendai, Japan) and maintained at $37^{\circ} \mathrm{C}$ in a humidified atmosphere containing $5 \% \mathrm{CO}_{2}$. The culture medium consisted of Dulbecco's modified Eagle's medium, $100 \mathrm{U} / \mathrm{mL}$ penicillin, $100 \mu \mathrm{g} / \mathrm{mL}$ streptomycin, and $10 \%$ fetal bovine serum.

hRFC-HEK293 (R27) cells, hRFC-HEK293 (H27) cells, and HEK293-Mock cells were grown in Dulbecco's modified Eagle's medium containing $100 \mathrm{U} / \mathrm{mL}$ penicillin, $100 \mu \mathrm{g} / \mathrm{mL}$ streptomycin, $600 \mu \mathrm{g} / \mathrm{mL}$ antibiotic G418 sulfate, and $10 \%$ fetal bovine serum. The cells were seeded into multiwell plates coated with poly-D-lysine at a density of $1.0 \times 10^{5}$ cells/ well.

Uptake Study Hank's balanced salt solution (HBSS: $145 \mathrm{~mm} \mathrm{NaCl}, 3 \mathrm{~mm} \mathrm{KCl}, 1 \mathrm{~mm} \mathrm{CaCl} 2,0.5 \mathrm{~mm} \mathrm{MgCl}_{2}$ ) containing $5 \mathrm{mM} \mathrm{D}$-glucose and $5 \mathrm{~mm} \operatorname{MES}(\mathrm{pH} 6.0,6.5)$ was used as the uptake medium. HBSS containing $5 \mathrm{~mm}$ D-glucose and $5 \mathrm{~mm}$ HEPES ( $\mathrm{pH}$ 7.4) was used as the rinse and the uptake medium ( $\mathrm{pH} 7.0,7.4)$.

For the uptake study, the R27-hRFC-HEK293, H27-hRFCHEK293, and HEK293-Mock cells in the multiwell plates were rinsed twice and preincubated with the rinse medium ( $\mathrm{pH}$ 7.4) for $10 \mathrm{~min}$ at $37^{\circ} \mathrm{C}$. Uptake was initiated by adding $0.5 \mathrm{~mL}$ of the preincubated drug solution. The uptake medium ( $\mathrm{pH}$ 6.0-7.4) containing $\left[{ }^{3} \mathrm{H}\right]-\mathrm{L}-\mathrm{MTX}$, unlabeled L-MTX, and D-MTX was used as the drug solution. The drug solution was aspirated at the appropriate time to terminate the uptake. The cells were rinsed twice with ice-cold rinse medium $(\mathrm{pH} 7.4)$, and then lysed with $1 \mathrm{~mL}$ of $0.1 \%$ Triton ${ }^{\circledR} \mathrm{X}-100$. To determine the uptake amount of $\left[{ }^{3} \mathrm{H}\right]-\mathrm{L}-\mathrm{MTX}$, a $0.8-\mathrm{mL}$ aliquot of the cell lysate was transferred to a scintillation vial, to which $5 \mathrm{~mL}$ of Clear-sol I (Nacalai Tesque) was added, and the radioactivity was measured by liquid scintillation counting. To determine the uptake amount of D-MTX, a 1-mL aliquot of the cell lysate was mixed with $1 \mathrm{~mL}$ of acetonitrile and then vortexed. The mixture was then centrifuged at $825 \times \boldsymbol{g}$ for $15 \mathrm{~min}$, and the supernatant was filtered using a Cosmonice filter $\mathrm{S}(0.45 \mu \mathrm{m}$; Nacalai Tesque). The filtrate was dried under a gentle stream of nitrogen gas at $80^{\circ} \mathrm{C}$, and the residue was dissolved in $100 \mu \mathrm{L}$ of the mobile phase (see below). ${ }^{20)}$ A $20-\mu \mathrm{L}$ aliquot was injected into an LC-MS/MS system for analysis.

In the inhibition study, each inhibitor was added to the drug solution at an appropriate concentration, and the uptake of the drug was measured according to the procedure described above. The drugs and inhibitors were dissolved in dimethylsulfoxide (DMSO), with the final concentration of DMSO in the drug solution being set to no more than $1 \%$.

LC-MS/MS Conditions A Waters Micromass tandem quadrupole Quattro micro mass spectrometer (Waters, Milford, MA, U.S.A.) was coupled with a HPLC system via an electrospray ionization probe in the negative ion mode. An Inertsil ${ }^{\circledR}$ ODS-3 column $(5 \mu \mathrm{m}$ in particle size, $2.1 \times 150 \mathrm{~mm}$; GL Sciences Inc., Tokyo, Japan) was used for the HPLC analysis. The mobile phase consisted of solvent A (10 mm ammonium acetate, $0.05 \%$ formic acid, and 1\% isopropyl alcohol in water) and solvent B ( $0.05 \%$ formic acid and $1 \%$ isopropyl alcohol in acetonitrile), which were mixed in a ratio of $9: 1$ $(\mathrm{v} / \mathrm{v})$. The flow rate was adjusted to $0.2 \mathrm{~mL} / \mathrm{min}$, and an eluent emerging from the column between 4 and $10 \mathrm{~min}$ was directed into the mass spectrometer. The ionization conditions were as follows: capillary voltage, $2.9 \mathrm{kV}$; cone voltage, $46 \mathrm{~V}$; collision energy, $22 \mathrm{eV}$; source temperature, $150^{\circ} \mathrm{C}$; desolvation temperature, $220^{\circ} \mathrm{C}$; and collision gas, argon. The sample was analyzed in the multiple reaction monitoring mode of the mass 

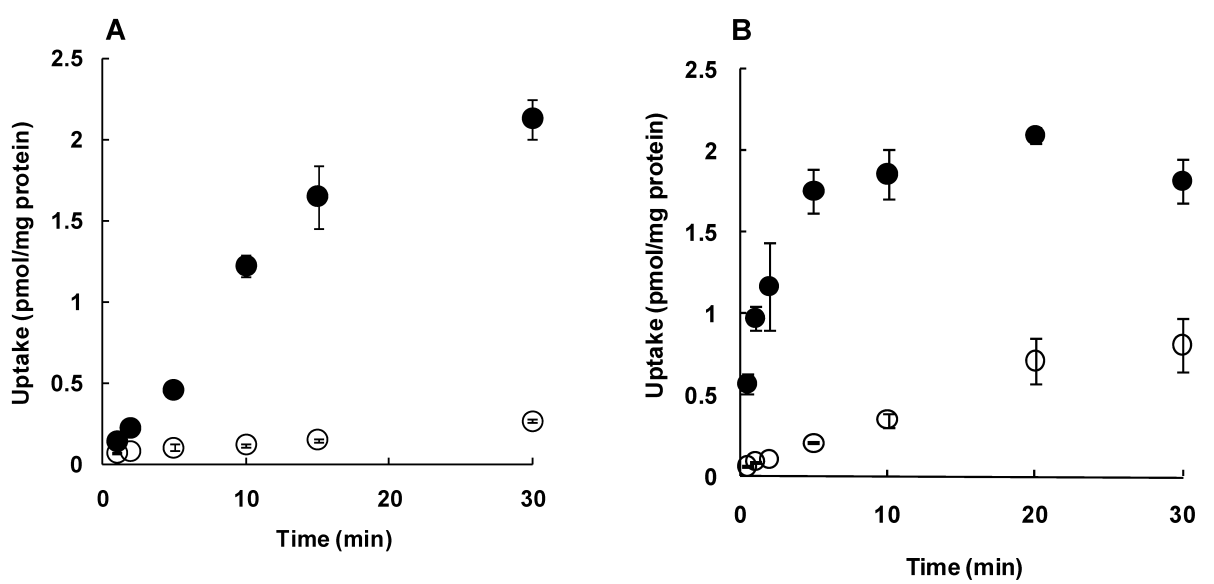

Fig. 1. Time Courses of $0.02 \mu \mathrm{M}$ L-MTX Uptake at an Extracellular pH of 7.4 into hRFC-HEK293 (H27-hRFC) Cells (A) and hRFC-HEK293 (R27hRFC) Cells (B)

Each point represents the mean \pm S.D. of three determinations. @: hRFC-transfected HEK293 cells, $\bigcirc$ : vector-transfected HEK293 cells (mock).

spectrometer with a dwell time of $2 \mathrm{~s}$ per channel using $\mathrm{m} / \mathrm{z}$ $453.08>324.08$ as the transition.

Western Blotting Analysis of the Cell Surface hRFC Proteins hRFC-HEK293 and mock cells in phosphatebuffered saline (PBS) (+) $\left(2 \mathrm{mM} \quad \mathrm{NaH}_{2} \mathrm{PO}_{4} \cdot 2 \mathrm{H}_{2} \mathrm{O}, 8 \mathrm{~mm}\right.$ $\mathrm{Na}_{2} \mathrm{HPO}_{4} \cdot 12 \mathrm{H}_{2} \mathrm{O}, \quad 137 \mathrm{~mm} \mathrm{NaCl}, \quad 0.9 \mathrm{~mm} \quad \mathrm{CaCl}_{2}, 0.33 \mathrm{~mm}$ $\mathrm{MgCl}_{2} \cdot 6 \mathrm{H}_{2} \mathrm{O}$ ) were treated for $30 \mathrm{~min}$ with $1 \mathrm{mg} / \mathrm{mL}$ EZ-Link Sulfo-NHS-SS-Biotin, which reacts with amino acid residues on the cell surface. The cells were then washed twice with $0.5 \mathrm{~mL}$ of PBS $(+)$ and treated with $0.4 \mathrm{~mL}$ of lysis buffer $(150 \mathrm{~mm} \mathrm{NaCl}, 10 \mathrm{~mm}$ Tris- $\mathrm{HCl}$ ( $\mathrm{pH} 8.8), 5 \mathrm{~mm}$ ethylenediaminetetraacetic acid (EDTA), $1 \mathrm{~mm}$ phenylmethylsulfonyl fluoride (PMSF), $50 \mu \mathrm{g} / \mathrm{mL}$ aprotinin, $10 \mu \mathrm{g} / \mathrm{mL}$ leupeptin, $1 \%$ Triton $^{\circledR} \mathrm{X}-100$ ) and kept on ice for $30 \mathrm{~min}$. The cells were then scraped from the plates before being centrifuged at $20600 \times \boldsymbol{g}$ for $15 \mathrm{~min}$ at $4^{\circ} \mathrm{C}$, and the supernatant was mixed with $40 \mu \mathrm{L}$ NeutrAvidin ${ }^{\mathrm{TM}}$ beads agarose resin. The samples were rotated overnight in a cold room $\left(4^{\circ} \mathrm{C}\right)$ and then centrifuged at $20600 \times \boldsymbol{g}$ for $2 \mathrm{~min}$ at $4^{\circ} \mathrm{C}$. The resulting pellets were initially washed with $0.5 \mathrm{~mL} \mathrm{PBS}(-)\left(2 \mathrm{~mm} \mathrm{NaH} \mathrm{PO}_{4} \cdot 2 \mathrm{H}_{2} \mathrm{O}\right.$, $8 \mathrm{mM} \mathrm{Na} \mathrm{HPO}_{4} \cdot 12 \mathrm{H}_{2} \mathrm{O}, 137 \mathrm{~mm} \mathrm{NaCl}$ ), before being washed sequentially with $0.5 \mathrm{~mL}$ of washing buffer $(150 \mathrm{~mm} \mathrm{NaCl}$, $10 \mathrm{~mm}$ Tris- $\mathrm{HCl}(\mathrm{pH} 8.8), 1 \%$ Triton $\left.^{\circledR} \mathrm{X}-100\right)$ and $0.5 \mathrm{~mL}$ of PBS (-). The pellets were then suspended in an sodium dodecyl sulfate-polyacrylamide gel electrophoresis (SDS-PAGE) sample buffer containing 2-mercaptoethanol and the proteins were released from the beads by heating at $100^{\circ} \mathrm{C}$ for $3 \mathrm{~min}$.

Protein samples were electrophoresed on $9 \%$ polyacrylamide gels in the presence of SDS. Following the electrophoresis, the proteins were transferred to an Immobilon-P transfer membrane (Millipore, Bedford, MA, U.S.A.) and blocked with $5 \%$ non-fat dried milk in PBS-T $\left(2 \mathrm{~mm} \mathrm{NaH} \mathrm{PO}_{4} \cdot 2 \mathrm{H}_{2} \mathrm{O}\right.$, $8 \mathrm{~mm} \mathrm{Na} \mathrm{HPO}_{4} \cdot 12 \mathrm{H}_{2} \mathrm{O}, 137 \mathrm{~mm} \mathrm{NaCl}, 0.1 \%$ polyoxyethylene sorbitan monolaurate (Tween 20)) at ambient temperature for $1 \mathrm{~h}$. The blots were probed with an anti-RFC antibody $(1: 200$ in PBS-T, 5\% non-fat dried milk; Santa Cruz Biotechnology, Dallas, TX, U.S.A.) and an anti- $\mathrm{Na}^{+} / \mathrm{K}^{+}$ATPase antibody (1:18000 in PBS-T, 5\% non-fat dried milk; Abcam, Cambridge, U.K.). Following the application of the first antibody, the blot was probed with an anti-rabbit immunoglobulin G (IgG) horseradish peroxidase conjugate $(1: 16000$ in PBS-T, 5\% non-fat dried milk; Sigma-Aldrich, St. Louis, MO, U.S.A.) for RFC, as well as being probed with an anti-mouse IgG horseradish peroxidase conjugate (1:16000 in PBS-T, 5\% nonfat dried milk; Sigma-Aldrich) for $\mathrm{Na}^{+} / \mathrm{K}^{+}$ATPase. The blots were then developed with Chemi-Lumi One Super (Nacalai Tesque) and their densitometry evaluated using the ImageJ software (National Institute of Health, Bethesda, MD, U.S.A.; http://rsbweb.nih.gov/ij/download.html). $\mathrm{Na}^{+} / \mathrm{K}^{+}$ATPase was used as a loading control.

Protein Assay For protein determination, the R27-hRFCHEK293, H27-hRFC-HEK293, and HEK293-Mock cells were dissolved in $1 \mathrm{~mL}$ of $0.1 \%$ Triton ${ }^{\circledR} \mathrm{X}-100$, and their protein concentrations determined using a Bio-Rad protein assay kit (Bio-Rad Laboratories, Richmond, CA, U.S.A.) with bovine serum albumin as a standard.

Data Analysis To calculate the kinetic parameters for L-MTX uptake, the data were fitted to the following equation using a non-linear least-squares method. ${ }^{21)}$

$$
v=\frac{V_{\max } \cdot[\mathrm{S}]}{K_{\mathrm{m}}+[\mathrm{S}]}
$$

where $v$ is the carrier-mediated initial uptake rate, $V_{\max }$ is the maximum uptake rate, $K_{\mathrm{m}}$ is the Michaelis constant, and [S] is the initial concentration of the drug.

\section{RESULTS}

Uptake of L-MTX Time courses of the $\left[{ }^{3} \mathrm{H}\right]-\mathrm{L}-\mathrm{MTX}$ uptake into the H27- and R27-hRFC-HEK293 cells are shown in Figs. $1 \mathrm{~A}$ and $\mathrm{B}$, respectively. The concentration of the $\left[{ }^{3} \mathrm{H}\right]$-L-MTX was $0.02 \mu \mathrm{M}$. The uptake was significantly higher in the H27- and R27-hRFC-HEK293 cells than it was in the mock cells. Based on the results in Fig. 1, it was possible to calculate the initial uptakes from the uptake amounts at 5 and $0.5 \mathrm{~min}$ for the H27- and R27-hRFC-HEK293 cells, respectively, from the following studies.

The $\mathrm{pH}$-dependent uptake plots of $0.02 \mu \mathrm{M}\left[{ }^{3} \mathrm{H}\right]$-L-MTX into the H27- and R27-hRFC-HEK293 cells are shown in Figs. 2A and $\mathrm{B}$, respectively. The uptake was measured in the extracellular $\mathrm{pH}$ range of 6.0-7.4. The $\mathrm{pH}$ profiles for the L-MTX uptake were similar for the H27- and R27-hRFC-HEK293 cells with the uptake being higher under neutral conditions than it was under acidic conditions. 

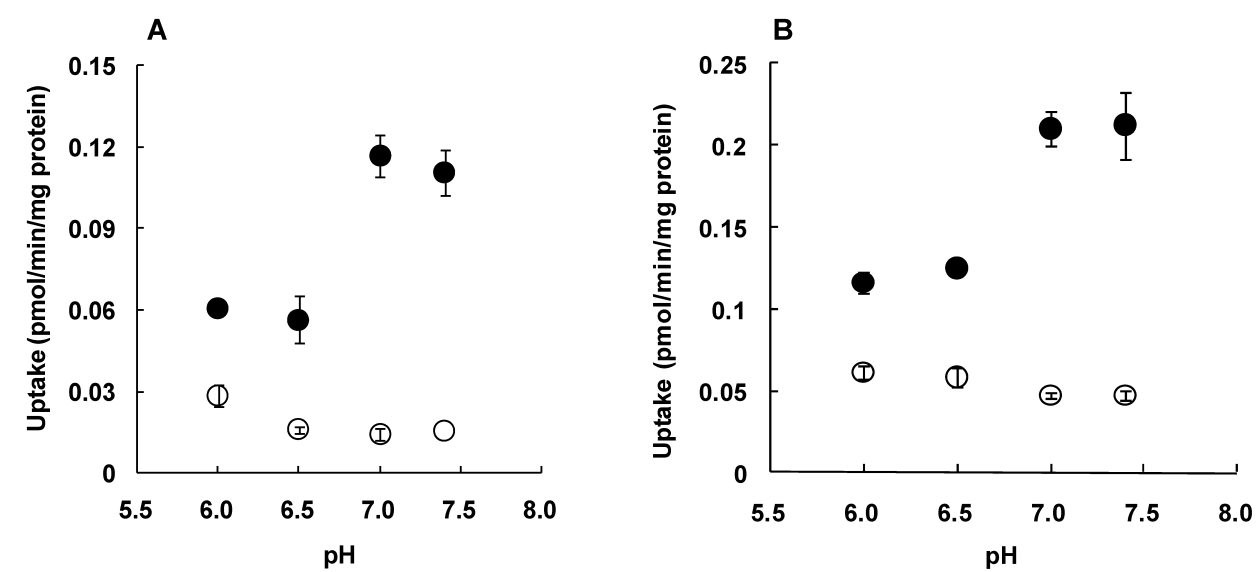

Fig. 2. The pH-Dependent Uptake of $0.02 \mu \mathrm{m}$ L-MTX into the H27-hRFC-HEK293 Cells (A) and R27-hRFC-HEK293 Cells (B)

The initial uptake rates were calculated from the uptake amounts in 5 and $0.5 \mathrm{~min}$ for the $\mathrm{H} 27$ and R27 cells, respectively. Each point represents the mean \pm S.D. of three determinations. : hRFC-transfected HEK293 cells, $\bigcirc$ : vector-transfected HEK293 cells (mock).
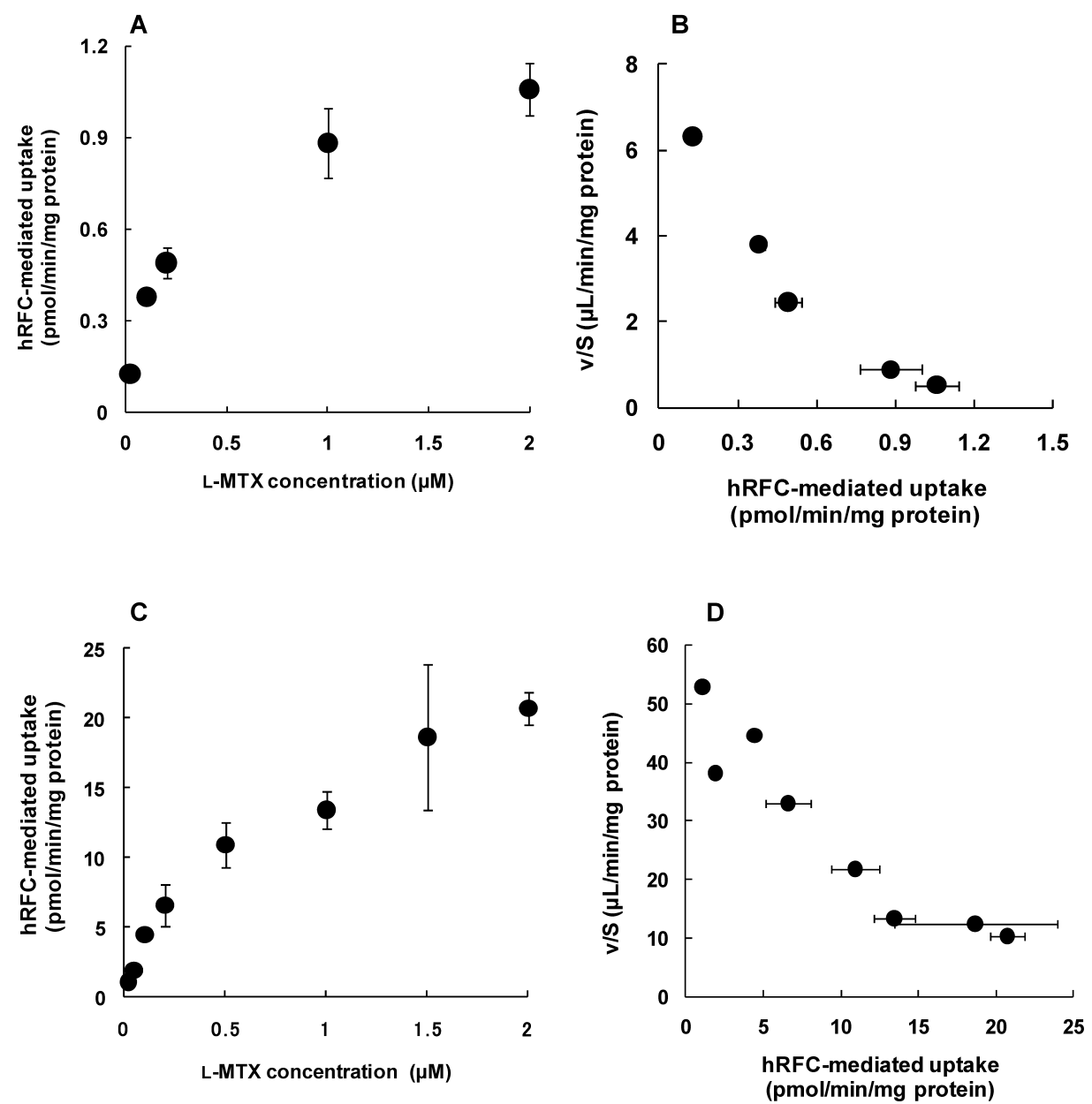

Fig. 3. Carrier-Mediated Uptakes at Different Concentrations of L-MTX for H27-hRFC (A) and R27-hRFC (C)

An Eadie-Hofstee plot of the carrier-mediated uptake of L-MTX for H27-hRFC (B) and R27-hRFC (D). Each point represents the mean \pm S.D. of three determinations. The carrier-mediated uptake was calculated by subtracting the uptake into mock cells from the uptake into hRFC-HEK293 cells.

The initial uptake rates of the $\left[{ }^{3} \mathrm{H}\right]-\mathrm{L}-\mathrm{MTX}$ at different concentrations $(0.02-2 \mu \mathrm{M})$ were measured at a $\mathrm{pH}$ of 7.4 in the H27- and R27-hRFC-HEK293 cells. The hRFC-mediated uptake was calculated by subtracting the uptake into the mock cells from the uptake into the hRFC-expressing cells, and the results are shown in Figs. 3A and C for the H27- and R27-hRFC-HEK293 cells, respectively. Eadie-Hofstee plots of the hRFC-mediated uptake are also shown in Figs. 3B and D for the H27- and R27-hRFC-HEK293 cells, respectively. The EadieHofstee plots indicated that the saturable uptake of L-MTX was mediated by a single transport system for the H27- and R27-hRFCs. The uptake parameters were calculated according to Eq. 1 and found to be $K_{\mathrm{m}}=0.235 \mu \mathrm{M}$ and $V_{\max }=1.14 \mathrm{pmol} / \mathrm{min} / \mathrm{mg}$ protein for $\mathrm{H} 27-\mathrm{hRFC}$, and 
$K_{\mathrm{m}}=0.472 \mu \mathrm{M}$ and $V_{\max }=22.6 \mathrm{pmol} / \mathrm{min} / \mathrm{mg}$ protein for R27hRFC (Table 1). Since AIC (Akaike's information criteria) value was smaller when the data were analyzed with one saturable component $(\mathrm{AIC}=-20.8$ and -15.0 for $\mathrm{H} 27$ and $\mathrm{R} 27$, respectively) than with two saturable components (AIC $=-19.2$ and -11.1 for $\mathrm{H} 27$ and $\mathrm{R} 27$, respectively), it was judged that the uptake into cells was by a single transport system.

Inhibition Studies In the H27-hRFC-HEK293 cells, the initial uptake rates of $0.02,0.04$, and $0.2 \mu \mathrm{M}\left[{ }^{3} \mathrm{H}\right]-\mathrm{L}-\mathrm{MTX}$ were measured at $\mathrm{pH} 7.4$ in the presence of $0,0.2$, and $0.4 \mu \mathrm{M}$ of unlabeled L-MTX, respectively. The H27-hRFC mediated uptake data were analyzed using a Dixon plot (Fig. 4A). The unla-

Table 1. Kinetic Parameters

\begin{tabular}{lccc}
\hline \hline & \multicolumn{3}{c}{ L-MTX } \\
\cline { 2 - 4 } & $\begin{array}{c}K_{\mathrm{m}} \\
(\mu \mathrm{M})\end{array}$ & $\begin{array}{c}V_{\max } \\
(\mathrm{pmol} / \mathrm{min} / \mathrm{mg} \text { protein })\end{array}$ & $\begin{array}{c}\text { Normalized } \\
V_{\max }\end{array}$ \\
\hline H27-hRFC & $0.235 \pm 0.042$ & $1.14 \pm 0.06$ & 12.7 \\
R27-hRFC & $0.472 \pm 0.075$ & $22.6 \pm 2.3$ & 22.6 \\
\hline
\end{tabular}

Values are expressed as mean \pm S.D., $n=3$. Normalized $V_{\max }$ was calculated by dividing $V_{\max }$ by the relative intensity of the Western blot (Fig. 6 ).

A
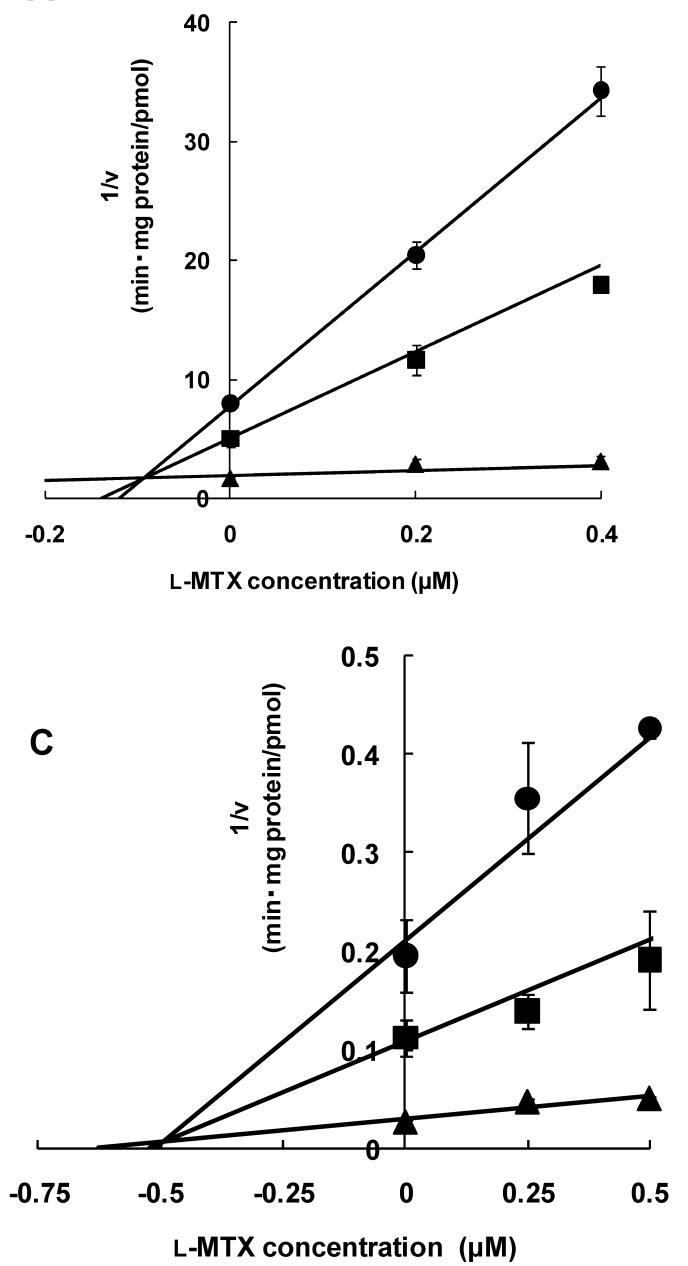

beled L-MTX competitively inhibited $\left[{ }^{3} \mathrm{H}\right]$-L-MTX uptake with a $K_{\mathrm{i}}$ value of $0.095 \mu \mathrm{M}$. Furthermore, the initial uptake rates of $0.02,0.04$, and $0.2 \mu \mathrm{M}\left[{ }^{3} \mathrm{H}\right]$-L-MTX into the H27-hRFCHEK293 cells were measured in the presence of 0,5 , and $10 \mu \mathrm{M}$ of D-MTX, respectively. Dixon plot analysis showed that the D-MTX competitively inhibited the $\left[{ }^{3} \mathrm{H}\right]$-L-MTX uptake with a $K_{\mathrm{i}}$ value of $3.41 \mu \mathrm{M}$ (Fig. 4B).

In the R27-hRFC-HEK293 cells, the initial uptake rates of $0.02,0.05$, and $0.2 \mu \mathrm{M}\left[{ }^{3} \mathrm{H}\right]-\mathrm{L}-\mathrm{MTX}$ were measured at $\mathrm{pH} 7.4$ in the presence of $0,0.25$, and $0.5 \mu \mathrm{M}$ of unlabeled L-MTX, respectively. Dixon plot analysis of the R27-hRFC mediated uptake showed that the unlabeled L-MTX inhibited the $\left[{ }^{3} \mathrm{H}\right]$ L-MTX uptake in a competitive manner with a $K_{\mathrm{i}}$ value of $0.493 \mu \mathrm{M}$ (Fig. 4C). The initial uptake rates of $0.02,0.05$, and $0.2 \mu \mathrm{M}\left[{ }^{3} \mathrm{H}\right]$-L-MTX were also measured in the presence of 0 , 2 , and $4 \mu \mathrm{M}$ of $\mathrm{D}-\mathrm{MTX}$, respectively. The associated Dixon plot showed that the D-MTX competitively inhibited the $\left[{ }^{3} \mathrm{H}\right]-$ L-MTX uptake with a $K_{\mathrm{i}}$ value of $3.22 \mu \mathrm{M}$ (Fig. 4D).

Comparison of $\mathrm{L}^{-}$and D-MTX Uptake The uptake of $0.02 \mu \mathrm{M}\left[{ }^{3} \mathrm{H}\right]-\mathrm{L}-\mathrm{MTX}$ and $1 \mu \mathrm{M}$ D-MTX into the H27- and R27hRFC-HEK293 cells was measured at $\mathrm{pH}$ 7.4. Uptake time of L-MTX was $5 \mathrm{~min}$ in $\mathrm{H} 27$ cells and $0.5 \mathrm{~min}$ in R27 cells, and that of D-MTX was $10 \mathrm{~min}$ in both cells. Since the reduction
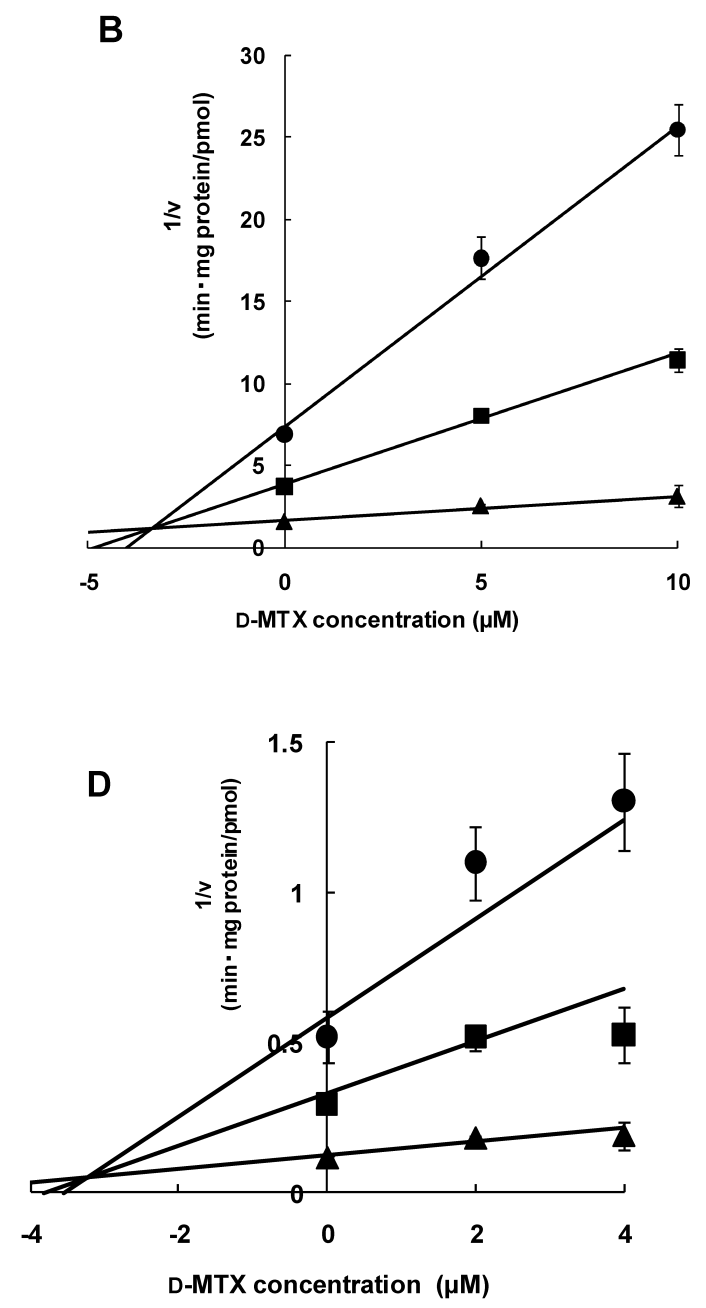

Fig. 4. Dixon Plots for the Inhibitory Effects of Unlabeled L-MTX and D-MTX on the hRFC-Mediated Uptake

Uptake of [ $\left.{ }^{3} \mathrm{H}\right]$-L-MTX by H27-hRFC was measured at $0.02(\mathbf{O}), 0.04(\mathbf{\square})$, and $0.2(\mathbf{\Delta}) \mu \mathrm{M}$ of the substrate in the presence of $0,0.2$, and $0.4 \mu \mathrm{M}$ L-MTX as an inhibitor (A); and 0,5 , and $10 \mu \mathrm{M}$ D-MTX as an inhibitor (B). The uptake of $\left[{ }^{3} \mathrm{H}\right]-\mathrm{L}-\mathrm{MTX}$ by R27-hRFC was measured at $0.02(\boldsymbol{\bullet}), 0.05(\mathbf{\square})$, and $0.2(\boldsymbol{\Delta}) \mu \mathrm{M}$ of the substrate in the presence of $0,0.25$, and $0.5 \mu \mathrm{M}$ L-MTX as an inhibitor (C); and 0,2 , and $4 \mu \mathrm{M}$ D-MTX as an inhibitor (D). Each point represents the mean \pm S.D. of three determinations. 
A

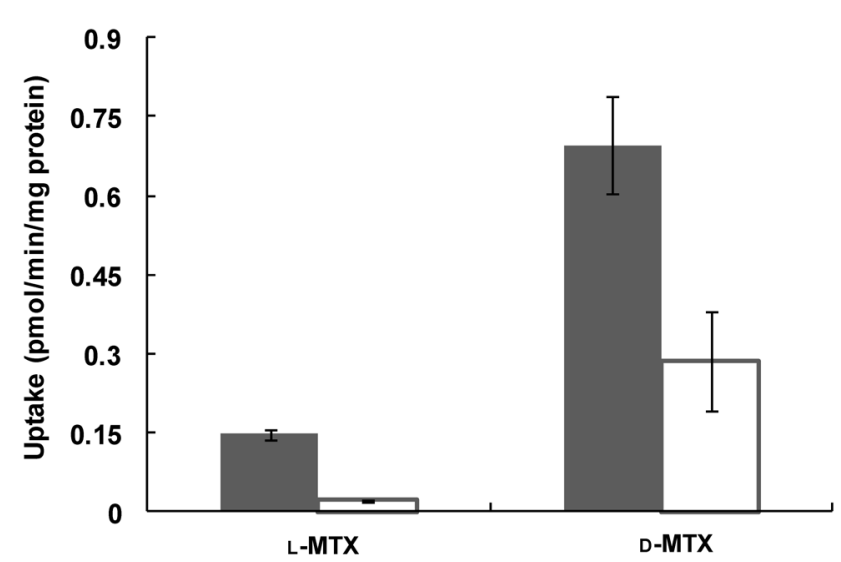

B

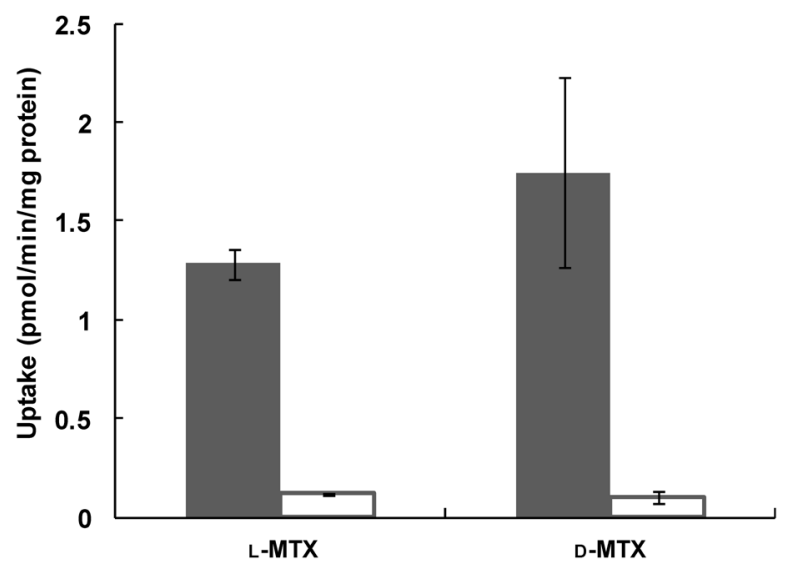

Fig. 5. Uptake of $0.02 \mu \mathrm{M} \mathrm{L-MTX}$ and $1 \mu \mathrm{M}$ D-MTX.

The uptake of L-MTX by H27-hRFC was measured for 5 min (A) and the uptake by R27-hRFC was measured for 0.5 min (B). The uptake of D-MTX was measured for $10 \mathrm{~min}$ in both cells. $\mathbf{\square}$ : hRFC-transfected HEK293 cells, $\square$ : vector-transfected HEK293 cells (mock). Each column represents the mean \pm S.D. of three determinations.

in uptake clearance was not observed for $10 \mathrm{~min}$ in our preliminary time course study, the uptake of D-MTX at 10 min was judged in the linear range (data not shown). The uptake of $\left.{ }^{3} \mathrm{H}\right]-\mathrm{L}-\mathrm{MTX}$ was measured by liquid scintillation counting, whereas the uptake of D-MTX was measured by LC-MS/MS. When the uptake of $10 \mu \mathrm{M} \mathrm{L}-\mathrm{MTX}$ was measured by liquid scintillation counting and LC-MS/MS, no discernible differences were observed in the uptake amounts determined by the different analytical methods (data not shown). The uptake of $\left[{ }^{3} \mathrm{H}\right]-\mathrm{L}-\mathrm{MTX}$ could therefore be compared with that of D-MTX. The initial uptake rates of L- and D-MTX are shown in Figs. 5A and B for the H27- and R27-hRFC-HEK293 cells, respectively.

The carrier-mediated uptake rate was calculated by subtracting the uptake into mock cells from the value of the uptake into the hRFC-expressing cells, and the uptake clearance was then calculated by dividing the carrier-mediated uptake rate by the initial concentration $(0.02 \mu \mathrm{M}$ for L-MTX and $1 \mu \mathrm{M}$ for D-MTX). The H27-hRFC-mediated uptake clearances of L- and D-MTX were 6.28 \pm 0.52 and $0.41 \pm 0.09 \mu \mathrm{L} / \mathrm{min} / \mathrm{mg}$ protein (mean \pm S.D., $n=3$ ), respectively, indicating that the uptake of L-MTX was approximately 15 -fold greater than that of D-MTX. In contrast, the R27-hRFC-mediated uptake clearances of L- and D-MTX were $58.1 \pm 3.8$ and $1.65 \pm 0.48 \mu \mathrm{L} /$ $\mathrm{min} / \mathrm{mg}$ protein (mean \pm S.D., $n=3$ ), respectively. These results revealed that the L-MTX uptake by the R27-hRFC was approximately 35 -fold greater than that of D-MTX.

Cell Surface Expression of hRFC Proteins The results of the Western blotting analyses of the cell membranes obtained from the R27-hRFC, H27-hRFC, and mock-HEK293 cells are shown in Fig. 6. The RFC proteins were detected in the R27- and H27-hRFC-HEK293 cells. The expression level of the R27-hRFC protein normalized by that of the $\mathrm{Na}^{+}$/ $\mathrm{K}^{+}$ATPase protein was about 10 -fold greater than that of the H27-hRFC protein. The broad band of the hRFC is consistent with the glycosylation of this protein, as previously reported. $^{22)}$

\section{DISCUSSION}

In our previous studies, we demonstrated that the highly
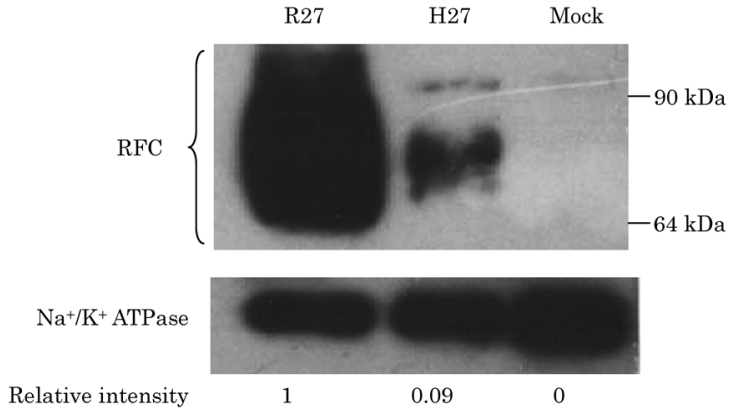

Fig. 6. Western Blotting Analyses of the R27-hRFC-, H27-hRFC-, and Vector-Transfected HEK293 Cells (Mock)

Proteins biotinylated at the cell surface were probed with an anti-RFC antibody and an anti- $\mathrm{Na}^{+} / \mathrm{K}^{+}$ATPase antibody. The relative level of RFC expression was calculated as the band intensity of the RFC divided by that of $\mathrm{Na}^{+} / \mathrm{K}^{+}$ATPase.

stereoselective intestinal absorption of L- and D-MTX occurred as a consequence of stereoselective transport by hPCFT. ${ }^{15)}$ Our investigation of hPCFT-expressing cells showed that L- and D-MTX are both substrates for hPCFT and that the $K_{\mathrm{m}}$ value of L-MTX $(4.98 \mu \mathrm{M})$ was significantly smaller than that of D-MTX $(211 \mu \mathrm{M})$. The results revealed that there are significant differences in the affinity of the enantiomers to hPCFT that resulted in the highly stereoselective absorption of the MTX enantiomers.

hPCFT transports reduced and oxidized folates using a $\mathrm{H}^{+}$ gradient as the driving force for the transportation process. Although the sequence homology between the amino acid sequences of hRFC and hPCFT is only about $10 \%$, reduced folates are transported by both of these systems. To date, there have been no reports in the literature to suggest that hRFC could behave as a stereoselective transporter. With this in mind, HEK293 cells stably expressing hRFC were established in the current study to examine the stereoselective transport of MTX enantiomers by hRFC. Since isotope-labeled D-MTX was not commercially available, the uptake of D-MTX was measured by LC-MS/MS.

It is noteworthy that the transport of folic acid (an oxidized folate) by hRFC was not observed in the established hRFC-expressing cells in the current study (data not shown). 
The results of a $\mathrm{pH}$-dependent uptake study revealed that the carrier-mediated uptake of L-MTX was higher under neutral conditions than it was under acidic conditions for the H27and R27-hRFCs (Fig. 2). The pH-dependent uptake observed in the current study for hRFC ( $\mathrm{pH}$ 6.0-7.4) was similar to that reported previously ( $\mathrm{pH} 5.0-8.0){ }^{12)}$

The $K_{\mathrm{m}}$ values for the H27- and R27-hRFCs were found to be similar at 0.235 and $0.472 \mu \mathrm{M}$, respectively (Table 1). These values were lower than those reported previously, which were $2.38 \mu \mathrm{M}$ for K562 cells transfected with human RFC (R27) cDNA, $1.62-3.04 \mu \mathrm{M}$ for K562 cells transfected with human RFC (H27) cDNA, ${ }^{23)} 1.31 \mu \mathrm{M}$ for $\mathrm{CHO}$ cells transfected with human RFC cDNA, ${ }^{24)}$ and $1.7 \mu \mathrm{M}$ for HepG2 cells transfected with human RFC cDNA. ${ }^{12)}$ Recently, it has been reported that two binding sites, high- and low-affinity sites, exist in organic anion transporting polypeptide 2B1(OATP2B1). ${ }^{25)}$ However, existence of two binding sites has not been reported for RFC and this study has also showed a single transport system for the transporter. The low affinity site may be revealed if the transport is measured at very high MTX concentrations.

The Dixon plots showed that L-MTX uptake by hRFC was inhibited in a competitive manner by the unlabeled L-MTX in the H27- and R27-hRFC-expressing cells with $K_{\mathrm{i}}$ values of 0.095 and $0.493 \mu \mathrm{M}$, respectively (Figs. 4A, C). The $K_{\mathrm{i}}$ values in this case were almost equal to the corresponding $K_{\mathrm{m}}$ values for L-MTX $(0.235$ and $0.472 \mu \mathrm{M}$ for the H27- and R27-hRFCs, Table 1). D-MTX also inhibited the uptake of L-MTX in a competitive manner with $K_{\mathrm{i}}$ values of 3.41 and $3.22 \mu \mathrm{M}$ for the H27- and R27-hRFCs, respectively (Figs. 4B, D). These results clearly demonstrate that the affinity of D-MTX to hRFC is at least 6-fold less than that of L-MTX.

The RFC-mediated uptake clearance rates for L-MTX and D-MTX were calculated as the uptake rates divided by the initial substrate concentrations. The resulting uptake clearance values for $\mathrm{H} 27-\mathrm{hRFC}$ were 6.28 and $0.41 \mu \mathrm{L} / \mathrm{min} / \mathrm{mg}$ protein for L-MTX and D-MTX, respectively. The uptake clearances of L-MTX and D-MTX were 58.1 and $1.65 \mu \mathrm{L} / \mathrm{min} / \mathrm{mg}$ protein for R27-hRFC. The ratios of the RFC-mediated uptake clearances of L-MTX to those of D-MTX were approximately 15 and 35 for the H27- and R27-hRFCs, respectively. When the RFC-mediated uptake clearances for L-MTX were calculated according to $V_{\max }$ divided by $K_{\mathrm{m}}$ (Fig. 3), the values were 4.85 and $47.9 \mu \mathrm{L} / \mathrm{min} / \mathrm{mg}$ protein for the H27- and R27-hRFCs, respectively. These uptake clearance values were similar to the values reported above.

Pharmacologically effective isomer is L-MTX, and this isomer is used clinically as an antineoplastic and antirheumatic drug. The therapeutic effect of L-MTX has been reported to be dependent on the SNP of hRFC in patients with rheumatoid arthritis or childhood acute lymphoblastic leukemia. ${ }^{26,27)}$ It has also been reported that the transport parameters of L-MTX were very similar in the H27- and R27-hRFCs when the transporters were expressed stably in K562 cells, although minor differences were observed in the $K_{\mathrm{i}}$ values of other anti-folates. ${ }^{22)}$ In the current study, the $K_{\mathrm{m}}$ of L-MTX in R27hRFC-HEK293 cells was approximately 2-fold greater than it was in H27-hRFC-HEK293 cells, and the $V_{\max }$ of L-MTX in R27-hRFC was approximately 20-fold greater than that in H27-hRFC (Fig. 3). When the $V_{\max }$ values were normalized based on the intensity of the bands in the Western blots (Fig. 6), the $V_{\max }$ values became 22.6 and 12.7 for the R27- and
H27-hRFCs, respectively (Table 1). Given that the L-MTX concentrations in plasma are similar or higher than the $K_{\mathrm{m}}$ value, the higher $V_{\max }$ value of R27-hRFC may have resulted in lower concentrations of L-MTX in patients with the R27 mutant than those with the $\mathrm{H} 27$ mutant, ${ }^{27}$ ) although $\mathrm{CL}_{\text {uptake }}$ (normalized $V_{\max } / K_{\mathrm{m}}$ ) values were not different statistically between H27-RFC and R27-RFC.

The stereoselectivity properties of other transporters have also been reported. For example, it has been reported that Lleucine transport by the L-type amino acid transporter (LAT1, SLC7A5) is about 3-fold greater than that of D-leucine. ${ }^{28)}$ The monocarboxylate transporter (MCT1, SLC16A1), which transports a variety of different organic acids such as lactic and pyruvic acid, shows stereoselective transport ${ }^{29)}$ and the affinity of L-lactic acid to MCT1 has been reported to be 3.2-fold greater than that of D-lactic acid. ${ }^{30)}$ Carnitine is transported by novel organic cation transporter 2 (OCTN2, SLC22A5), and the affinity of L-carnitine to OCTN2 is 20 -fold greater than that of D-carnitine. ${ }^{31)}$ Organic cation transporter 1 (OCT1, SLC22A1) is involved in the transport of various organic cations and shows significant levels of stereoselectivity, with the affinity of $(R)$-verapamil for OCT1 being 70 -fold greater than that of $(S)$-verapamil. ${ }^{32)}$ In addition to those influx transporters, efflux transporters also exhibit some stereoselectivity. For example, it has been reported that L- and D-MTX are both transported by rat mrp2 and that the affinity of D-MTX for rat mrp2 is 3.5 -fold greater than that of L-MTX. ${ }^{33)}$ It ahs also been reported that the efflux clearance ( $V_{\max } / K_{\mathrm{m}}$ ratios) of $N$-methylquinidine by P-glycoprotein (P-gp, MDR1, ABCB1) is about 3-fold greater than its diastereomer, $N$-methylquinine. ${ }^{34)}$ The stereoselectivity observed in the current study for hRFC appears to be comparable with or greater than that of many other known transporters.

The current study has revealed for the first time the stereoselectivity of the hRFC-mediated transport of the enantiomers of MTX. The R27 and H27 mutants of hRFC both showed stereoselective transport properties, although the transport of L-MTX was approximately 30 -fold greater than that of D-MTX because of the higher affinity of this enantiomer for the hRFC. Furthermore, the current results indicate that the higher $V_{\max }$ value of the R27 mutant compared with the H27 mutant may have led to significantly lower concentrations of L-MTX in the plasma of the patients with the R27 mutant. To the best of our knowledge, there is no report on the expression level of RFC in patients. However, the recent study has reported that the polymorphism of three genes, RFC, aminoimidazole carboxamide ribonucleotide transformylase (ATIC), and inosine triphosphate pyrophosphatase (ITPA), influenced the effect of L-MTX in the rheumatoid arthritis treatment. ${ }^{35)}$ Since it has been reported that L-MTX concentrations in the blood of childhood acute lymphoblastic leukemia are different between R27 and H27 mutants, ${ }^{27}$ ) the SNPs of RFC could influence pharmacokinetics of L-MTX.

\section{REFERENCES}

1) Sirotnak FM, Tolner B. Carrier-mediated membrane transport of folates in mammalian cells. Annu. Rev. Nutr., 19, 91-122 (1999).

2) Matherly LH, Goldman ID. Membrane transport of folates. Vitam. Horm., 66, 403-456 (2003).

3) Qiu A, Jansen M, Sakaris A, Min SH, Chattopadhyay S, Tsai E, 
Sandoval C, Zhao R, Akabas MH, Goldman ID. Identification of an intestinal folate transporter and the molecular basis for hereditary folate malabsorption. Cell, 127, 917-928 (2006).

4) Zhao R, Matherly LH, Goldman ID. Membrane transporters and folate homeostasis: intestinal absorption and transport into systemic compartments and tissues. Expert Rev. Mol. Med., 11, e4 (2009).

5) Nguyen TT, Dyer DL, Dunning DD, Rubin SA, Grant KE, Said HM. Human intestinal folate transport: cloning, expression, and distribution of complementary RNA. Gastroenterology, 112, 783-791 (1997).

6) Dixon KH, Lanpher BC, Chiu J, Kelley K, Cowan KH. A novel cDNA restores reduced folate carrier activity and methotrexate sensitivity to transport deficient cells. J. Biol. Chem., 269, 17-20 (1994).

7) Moscow JA, Gong M, He R, Sgagias MK, Dixon KH, Anzick SL, Meltzer PS, Cowan KH. Isolation of a gene encoding a human reduced folate carrier (RFC1) and analysis of its expression in transport-deficient, methotrexate-resistant human breast cancer cells. Cancer Res., 55, 3790-3794 (1995).

8) Prasad PD, Ramamoorthy S, Leibach FH, Ganapathy V. Molecular cloning of the human placental folate transporter. Biochem. Biophys. Res. Commun., 206, 681-687 (1995).

9) Williams FM, Murray RC, Underhill TM, Flintoff WF. Isolation of a hamster cDNA clone coding for a function involved in methotrexate uptake. J. Biol. Chem., 269, 5810-5816 (1994).

10) Williams FM, Flintoff WF. Isolation of human cDNA that complements a mutant hamster cell defective in methotrexate uptake. J. Biol. Chem., 270, 2987-2992 (1995).

11) Wong SC, Proefke SA, Bhushan A, Matherly LH. Isolation of human cDNAs that restore methotrexate sensitivity and reduced folate carrier activity in methotrexate transport-defective Chinese hamster ovary cells. J. Biol. Chem., 270, 17468-17475 (1995).

12) Wang Y, Zhao R, Goldman ID. Characterization of a folate transporter in HeLa cells with a low $\mathrm{pH}$ optimum and high affinity for pemetrexed distinct from the reduced folate carrier. Clin. Cancer Res., 10, 6256-6264 (2004).

13) Qiu A, Min SH, Jansen M, Malhotra U, Tsai E, Cabelof DC, Matherly LH, Zhao R, Akabas MH, Goldman ID. Rodent intestinal folate transporters (SLC46A1): Secondary structure, functional properties, and response to dietary folate restriction. Am. J. Physiol. Cell Physiol., 293, C1669-C1678 (2007).

14) Hendel J, Brodthagen H. Entero-hepatic cycling of methotrexate estimated by use of the D-isomer as a reference marker. Eur. J. Clin. Pharmacol., 26, 103-107 (1984).

15) Narawa T, Itoh T. Stereoselective transport of amethopterin enantiomers by the proton-coupled folate transporter. Drug Metab. Pharmacokinet., 25, 283-289 (2010).

16) Whetstine JR, Flatley RM, Matherly LH. The human reduced folate carrier gene is ubiquitously and differentially expressed in normal human tissues : identification of seven non-coding exons and characterization of a novel promoter. Biochem. J., 367, 629-640 (2002).

17) Chango A, Emery-Fillon N, de Courcy GP, Lambert D, Pfister M, Rosenblatt DS, Nicolas JP. A polymorphism $(80 \mathrm{G}>\mathrm{A})$ in the reduced folate carrier gene and its associations with folate status and homocysteinemia. Mol. Genet. Metab., 70, 310-315 (2000).

18) Rady PL, Szucs S, Matalon RK, Grady J, Hudnall SD, Kellner LH, Nitowsky H. Genetic polymorphism (G80A) of reduced folate carrier gene in ethnic populations. Mol. Genet. Metab., 73, 285-286 (2001).

19) Hayashi H, Fujimaki C, Daimon T, Tsuboi S, Matsuyama T, Itoh $\mathrm{K}$. Genetic polymorphisms in folate pathway enzymes as a possible marker for predicting the outcome of methotrexate therapy in Japanese patients with rheumatoid arthritis. J. Clin. Pharm. Ther., 34, 355-361 (2009).

20) Sparreboom A, Loos WJ, Nooter K, Stoter G, Verweij J. Liquid chromatographic analysis and preliminary pharmacokinetics of methotrexate in cancer patients co-treated with docetaxel. J. Chromatogr. B Analyt. Technol. Biomed. Life Sci., 735, 111-119 (1999).

21) Yamaoka K, Tanigawara Y, Nakagawa T, Uno T. A pharmacokinetic analysis program (MULTI) for microcomputer. J. Pharmacobiodyn., 4, 879-885 (1981).

22) Wong SC, Zhang L, Proefke SA, Matherly LH. Effects of the loss of capacity for $N$-glycosylation on the transport activity and cellular localization of the human reduced folate carrier. Biochim. Biophys. Acta, 1375, 6-12 (1998).

23) Whetstine JR, Gifford AJ, Witt T, Liu XY, Flatley RM, Norris M, Haber M, Taub JW, Ravindranath Y, Matherly LH. Single nucleotide polymorphism in the human reduced folate carrier: characterization of a high-frequency G/A variant at position 80 and transport properties of the $\mathrm{His}^{27}$ and $\mathrm{Arg}^{27}$ carriers. Clin. Cancer Res., 7, 3416-3422 (2001).

24) Cao W, Matherly LH. Characterization of a cysteine-less human reduced folate carrier: localization of a substrate-binding domain by cysteine-scanning mutagenesis and cysteine accessibility methods. Biochem. J., 374, 27-36 (2003).

25) Shirasaka Y, Mori T, Shichiri M, Nakanishi T, Tamai I. Functional pleiotropy of organic anion transporting polypeptide OATP2B1 due to multiple binding sites. Drug Metab. Pharmacokinet., 27, 360-364 (2012).

26) Drozdzik M, Rudas T, Pawlik A, Gornik W, Kurzawski M, Herczynska M. Reduced folate carrier-1 $80 \mathrm{G}>\mathrm{A}$ polymorphism affects methotrexate treatment outcome in rheumatoid arthritis. Pharmacogenomics J., 7, 404-407 (2007).

27) Laverdière $\mathrm{C}$, Chiasson $\mathrm{S}$, Costea I, Moghrabi A, Krajinovic M. Polymorphism $\mathrm{G}_{80} \mathrm{~A}$ in the reduced folate carrier gene and its relationship to methotrexate plasma levels and outcome of childhood acute lymphoblastic leukemia. Blood, 100, 3832-3834 (2002).

28) Yanagida O, Kanai Y, Chairoungdua A, Kim DK, Segawa H, Nii T, Cha SH, Matuo H, Fukushima J, Fukasawa Y, Tani Y, Taketani Y, Uchino H, Kim JY, Inatomi J, Okayasu I, Miyamoto K, Takeda E, Goya T, Endou H. Human L-type amino acid transporter 1 (LAT1): characterization of function and expression in tumor cell lines. Biochim. Biophys. Acta, 1514, 291-302 (2001).

29) Meredith D, Christian HC. The SLC16 monocarboxylate transporter family. Xenobiotica, 38, 1072-1106 (2008).

30) Galić S, Schneider HP, Bröer A, Deitmer JW, Bröer S. The loop between helix 4 and helix 5 in the monocarboxylate transporter MCT1 is important for substrate selection and protein stability. Biochem. J., 376, 413-422 (2003).

31) Wagner CA, Lükewille U, Kaltenbach S, Moschen I, Bröer A, Risler T, Bröer S, Lang F. Functional and pharmacological characterization of human $\mathrm{Na}^{+}$-carnitine cotransporter hOCTN2. Am. J. Physiol., 279, F584-F591 (2000).

32) Moaddel R, Ravichandran S, Bighi F, Yamaguchi R, Wainer IW. Pharmacophore modeling of stereoselective binding to the human organic cation transporter (hOCT1). Br. J. Pharmacol., 151, 13051314 (2007).

33) Masuda M, I'izuka Y, Yamazaki M, Nishigaki R, Kato Y, Ni’inuma K, Suzuki H, Sugiyama Y. Methotrexate is excreted into the bile by canalicular multi specific organic anion transporter in rat. Cancer Res., 57, 3506-3510 (1997).

34) Hooiveld GJ, Heegsma J, van Montfoort JE, Jansen PL, Meijer DK, Müller M. Stereoselective transport of hydrophilic quaternary drugs by human MDR1 and rat Mdrlb P-glycoproteins. Br. J. Pharmacol., 135, 1685-1694 (2002).

35) Dervieux T, Wessels JA, Kremer JM, Padyukov L, Seddighzadeh M, Saevarsdottir S, van Vollenhoven RF, Klareskog L, Huizinga TW, Guchelaar HJ. Patterns of interaction between genetic and nongenetic attributes and methotrexate efficacy in rheumatoid arthritis. Pharmacogenet. Genomics, 22, 1-9 (2012). 